\title{
Perceptions of Educators, Accounting Students and Accountants Public Accountant against Ethics of Financial Statement Preparation (Studies at University and KAP in Semarang)
}

\author{
Imam Prayogo ${ }^{1}$, Teuku Afrizal ${ }^{2 *}$ \\ ${ }^{I}$ Department of Accounting, Faculty of Vocational School, Universitas Diponegoro, PSDKU Pekalongan, \\ Indonesia \\ ${ }^{2 *}$ Department of Public Administration, Faculty of Social and Political Sciences, Universitas Diponegoro, \\ Semarang, Indonesia \\ imamprayogo@lecturer.undip.ac.id,teukurian@lecturer.undip.ac.id*
}

\begin{abstract}
This study aims to examine differences in perceptions between teaching accountants, accounting students, and accountants on the ethics of preparing financial statements. Ethical indicators for the preparation of financial statements are represented in earnings management, misstatements, disclosures, cost-benefits, and responsibilities. This research was conducted at universities and public accounting firms in Semarang. This research was conducted with a survey method of 70 respondents from teaching accountants, 75 accounting students, and 40 accountants respondents at universities and public accounting firms in Semarang. As an analysis tool, ANOVA is used for hypotheses H1, H2, H3, and H4. Before testing the hypothesis, first the validity and reliability tests are carried out for all the questionnaires that have been collected. Validity and reliability tests show that all data are valid and reliable. Then the questionnaire was tested by ANOVA and strengthened by the Independent Sample T Test. Anova results show that there are differences in perceptions between teaching accountants, accounting students and accountants. However, there was no difference in perceptions between teaching accountants and accountants. Therefore it can be concluded that there are differences in perceptions between teaching accountants, accounting students, and accountants on the ethics of preparing financial statements.
\end{abstract}

\section{Keywords}

ethics of financial statement preparation; perceptions, teaching accountants accounting students, accountants

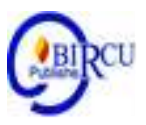

\section{Introduction}

It is common knowledge that the world of education in Indonesia is far behind compared to other countries in Asia. According to Saputra (2018) Education is considered to have a very important role in promoting the civilization of a nation. One of the contributing factors is the lack of ethics implementation in the education system. Every element in the education system must be able to apply ethical values so that synergies are obtained in developing the quality of education. Ethics teaching basically provides ethical knowledge to students only at the level of moral perception and moral judgment. To arrive at an action (action), students must have an awareness of divine values. According to Sugiharto (2020) Education is one of the efforts to improve the ability of human intelligence, thus he is able to improve the quality of his life.

The world of education is a producer that provides output in the form of human resources to society. The colors given by the world of education will also color people's behavior. Therefore, the development of an ethical and moral world of education is very important in order to form a civil society. 
Elements related to the development of the world of education are: (1) the government which regulates the world of education based on the provisions of regulations and laws, (2) educational institutions, (3) teachers / lecturers, and (4) students. The four elements are related to one another to form an education system.

The world of accounting education also has a great influence on the ethical behavior of an accountant. Therefore, the understanding of a prospective accountant (accounting student) is needed in terms of ethics and the existence of ethics education also has an important role in the development of the accounting profession in Indonesia. Subjects that contain ethical content are inseparable from the mission that accounting higher education has as a higher education subsystem, but higher education accounting is also responsible for teaching science related to ethics that students must have and so that students have personality who intact as a professional accountant candidate.

The accountant profession in Indonesia is now facing increasingly tough challenges. In addition, economic progress has prompted the emergence of new business actors, which has resulted in sharp business competition. But sometimes to achieve that goal, all efforts and actions are made even though business people must take actions that ignore various moral and ethical dimensions of business itself, including the accounting profession.

Financial statements are basically a source of information for investors as one of the basic considerations in making capital market investment decisions and also as a means of management responsibility for the resources entrusted to them. This shows that financial reports are an important medium for conveying corporate disclosure by company management and are an important source of information in making investors' decisions. So that financial reports that have been audited by a public accountant can be a useful basis for decision making, one way that can be taken is to create criteria for the need for certain disclosures that can cover all public companies (Baridwan, 1992: 1-6) in Subiyantoro (1996).

The preparation of financial reports considers many things, including the costbenefit, the period for which the financial statements are prepared, reliability, relevance, consistency, and so on. These considerations sometimes result in incomplete financial statement information. Earning management practices that are carried out can also cause confusion. Errors include miscalculations or writing in accounting records and data, errors in the application of accounting principles and misinterpretation of facts during the preparation of financial statements.

In addition to the specific objectives of company managers, conflicts can also arise from the level of disclosure of information in the financial statements. Financial statement users expect to get all the information they need from financial reports, while this information may not necessarily be available. Companies must pay the costs required to collect and provide information in the financial statements so that sometimes the amount of information disclosed by companies is very limited (Yulianti and Fitriany, 2005).

This research is a replication of research conducted by Gaa and Thorne in Yulianti and Fitriany (2005). The difference between this study and previous research lies in the respondents used. 


\section{Review of Literature}

\subsection{Stewardship Theory}

Stewardship theory describes the relationship between shareholders (prncipal) and managers (steward). This theory assumes that personal interests between managers and shareholders can be aligned through the achievement of organizational goals. Managers are motivated to maximize company performance so as to meet shareholder expectations and act in accordance with the goals of the organization. Managers with all the facilities and resources available to the company work for company goals, no longer prioritizing personal or personal interests. The manager as a steward will openly account for the assets he manages (the company) to shareholders through financial reports (Sanchez, 2007).

\subsection{Financial Statements}

When examining history, the knowledge related to the process of recording in the business world has been started since the Babylonian era in their trading business. However, the bookkeeping system emerged from practices in Venice. So in his book Luca Pacioli mentions this method as the Venetian Method (Irawan, 2006).

The financial report is the final result of the accounting cycle in the form of company financial information that describes the condition of the company which is used as a form of management responsibility for its performance so far.

\subsection{Preparation of Financial Statements}

Financial reports provide an overview of a company which is translated into currency (rupiah). The obligation to prepare financial reports as stipulated in Law no. 1/1995 regarding Limited Liability Companies (PT), especially in Chapter IV which consists of 5 articles that regulate the obligations of the Board of Directors to submit annual financial reports (Irawan, 2006).

In a broad sense, disclosure regarding information presented in the form of financial statements or other supporting communication media, such as: footnotes, post-date events, management analysis regarding operations in the coming year, financial and operational predictions and additional segmental financial reports. disclosure and other information outside of historical cost (Irawan, 2006).

\subsection{Perception}

Perception based on the Big Indonesian dictionary (1995) means direct response (acceptance) of something, or is the process of someone knowing things through their five senses. Meanwhile, according to Rakhmat (1993) in Ludigdo (1999) perception is the experience of objects, events, or relationships obtained by summarizing information and interpreting messages. Or in other words, perception is giving meaning to sensory stimuli.

A common thread can be drawn which explains that perception is a process that is related not only to the process of receiving stimuli, but also through cognitive processes. According to Sihotang (2019) Accounting courses are compulsory subjects for the Accounting Education Study Program, with emphasis on Cognitive aspects and Psychomotor aspects.

\subsection{Ethics}

Often people give the same meaning between morals and ethics. Moral comes from the Latin moralia, an adjective of mos (custom) and mores (behavior). Meanwhile, Ethics comes from the Greek word ethikos, the adjective of ethos (behavior). According to 
Suseno (1997) ethics is a philosophy or critical and fundamental thinking about teachings and moral views.

This research was conducted on prospective accountants (accounting students) because they are prospective accountants who should first be equipped with knowledge of ethics so that after graduating they can work professionally based on professional ethics and can apply ethics in a business environment.

\subsection{Ethics in Education Providers and Teachers}

The organizers of education are the government and educational institutions. The government carries out the mandate of the people through the People's Consultative Assembly (MPR) to organize national education. National education aims to educate humans, have knowledge and skills, have noble character and devotion to God Almighty.

Most professions have a code of ethics that is used as a control for their members to behave and behave ethically. However, the lecturer profession does not have an explicitly formulated code of ethics. In the United States, the teaching accounting professional organization, namely the American Accounting Association, also does not issue a separate code of ethics for educators. The reason is that the teaching profession in general is also involved in other professions that also have a code of ethics that must be obeyed (Utami, 2005).

\subsection{Ethics of Preparation of Financial Statements}

In this case, IAI took a policy to adopt a conceptual framework prepared by the IASC as the basis for the preparation and presentation of financial statements. The policy was approved by the Indonesian Accounting Principles Committee on August 24, 1994 and approved by the IAI Central Management on September 7, 1994. IAI named the Indonesian conceptual framework with the term "Basic Framework for the Preparation and Presentation of Financial Statements" (Chariri and Ghozali, 2003).

The basic assumptions in the framework for the preparation and presentation of financial statements state that there are two basic assumptions used in accounting, namely, the basis of the accrual concept and the going concern. Not much different from the FASB, IAI also emphasized the importance of the qualitative characteristics of financial information.

\subsection{Previous Research}

Nicholas and Okpara (2008) conducted research with the same theme as McCarthy (1997). Nicholas and Okpara wanted to evaluate the perceptions of ethical behavior towards students who took the accounting program for 5 years and their views on the accounting profession before and during the 21st century. The study was conducted in New York State with 300 students as the research sample. This study also explores Kohlberg's theory of moral development against the ethical reasons for the study sample. The results showed that students had a great deal of attention to the ethical behavior of the accountant profession. The development of students' ethical reasons is also in accordance with Kohlberg's theory.

Utami (2005) conducted research on ethics and the development of accounting teaching. Utami reviews ethics in education administration where the government and educational institutions are the organizers, ethics in teaching (accounting lecturers), and ethical content in teaching accounting. The results of this study reveal that ethical behavior is basically the end result of the process of (a) moral perception, (b) moral judgment, (c) 
moral intention, (d) moral action. Ethics teaching basically provides ethical knowledge to students only at the level of moral perception and moral judgment.

Meanwhile, Ludigdo (2006) examines the structuring of ethical practices in public accounting firms, measuring the level of ethical practice in public accounting firms. The research object, namely public accountants, with the understanding method (verstehen), this research develops a theoretical link, namely ethnomethodology, structure and spiritual intelligence (SQ). This linkage is intended to facilitate the realistic categorization of ethical practice and the various aspects that surround it. Data collection is done by describing, criticizing, and idealizing a situation. Structuration theory which is then strengthened by spiritual intelligence is used as a framework for analysis. The results of this research, in order to act with integrity, a company must articulate its values and priorities which are formulated in a mission, code of conduct, or code of ethics (Hartman (1998) in Ludigdo (006)). An in-depth study from various perspectives is needed on the ineffectiveness of the application of accounting professional ethics, especially in Indonesia.

\subsection{Framework}

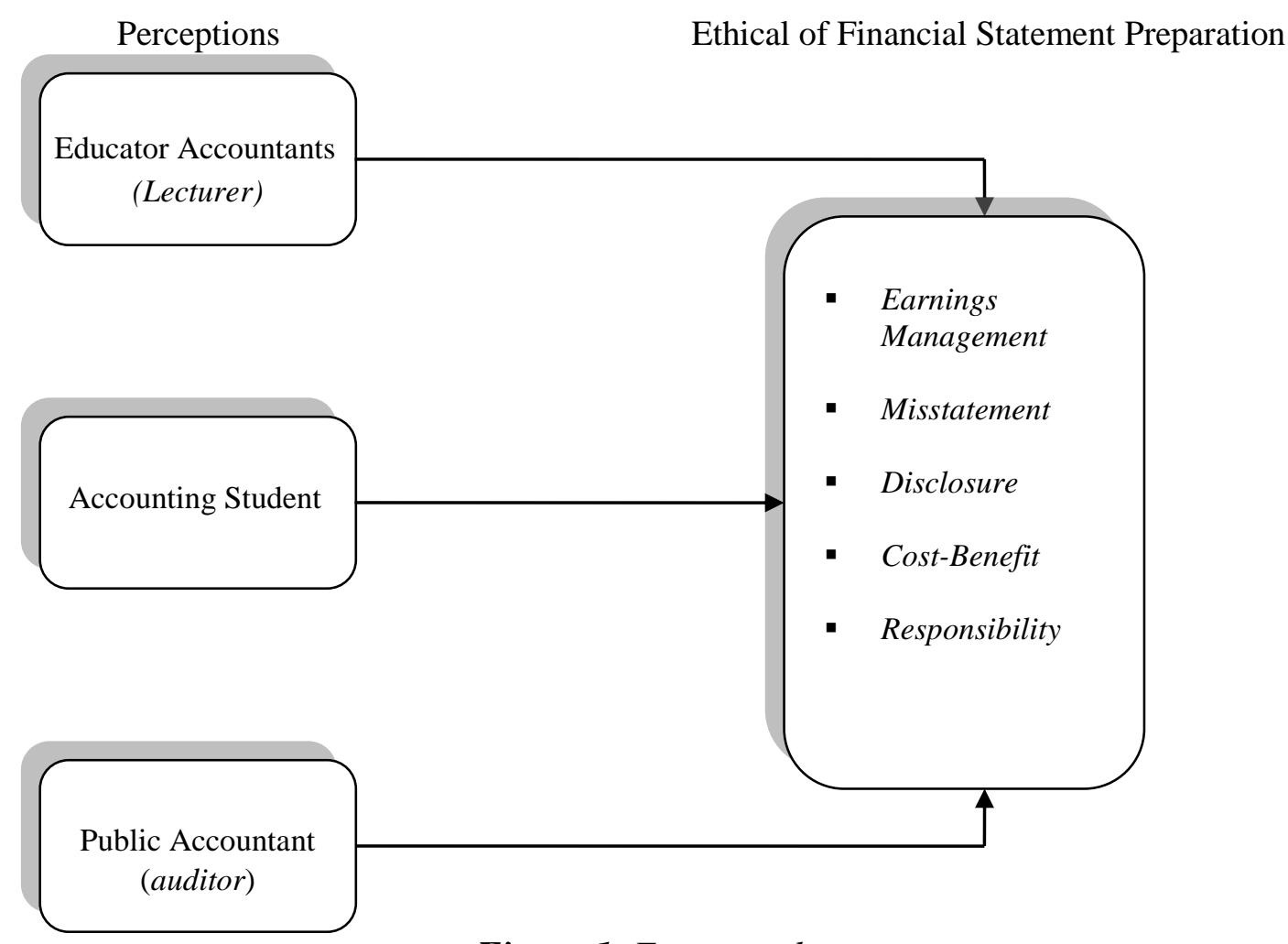

Figure 1. Framework

\subsection{Hypothesis}

Hypothesis is an opinion or conclusion that is still temporary (Lincolin Arsyad, 1999). The temporary nature of this hypothesis means that a hypothesis can be changed or replaced by another, more precise hypothesis. This is possible because the hypothesis obtained usually depends on the problems studied and the concepts used.

Perception is a process to understand the environment including objects, people, and symbols or signs that involve cognitive processes (learning). Cognitive process is a process where individuals give meaning through their interpretation of stimuli (stimuli) that arise from certain objects, people, and symbols. This means that if someone experiences a 
deeper learning process, it can be assumed that someone has a good perception. Utami (2005) conducted research on ethics and the development of accounting teaching. This research examines ethics in the administration of education where the government and educational institutions are the organizers, ethics in the teaching (accounting lecturers) and ethical content in teaching accounting. This research, reveals that ethical behavior is basically the end result of the process of (a) moral perception, (b) moral judgment, (c) moral intention, (d) moral action. Ethics teaching basically provides ethical knowledge to students only at the level of moral perception and moral judgment. Research by Fitriany and Yulianti (2005) suggests the need for changes to the accounting curriculum in Indonesia, particularly in terms of ethics and values of the accounting profession. The results of research by Fitriany and Yulianti (2005) show that students who have taken ethics education have a better perception of the ethics of financial statement presentation compared to students who have not taken ethics education. Ethics teaching basically provides ethical knowledge to students only at the level of moral perception and moral judgment.

Utami (2005) argues that most professions have a code of ethics that controls their members to behave and behave ethically. Meanwhile, Aprianti (2006) stated that public accountants as a profession also have the Indonesian Accountants Code of Ethics within the scope of the Indonesian Accountants Association (IAI) organization or organization. However, the lecturer profession does not have an explicitly formulated code of ethics. The reason is that the teaching profession in general is also involved in other professions that also have a code of ethics that must be obeyed (Utami, 2005). Different forms of code of ethics in public accountants and teaching accountants can affect the implementation of professional ethics.

Based on the description above and in previous studies, in this study the following hypotheses can be proposed:

H1: There are differences in perceptions between teaching accountants (lecturers), accounting students, and public accountants (auditors) on the ethics of preparing financial statements.

McCarthy (1997) research on ethical orientation towards the accounting profession, resulted in the conclusion that there was no development of ethical orientation (AICPA code of ethics) in accounting teaching at the university level. This is in line with the research of Suranta and Martadi (2006) regarding perceptions of business ethics and professional ethics in the group of accountants, accounting students and accounting employees who state the conclusion that there are no differences in perceptions about business ethics between accountants, accounting students and accounting employees .

However, Nicholas and Okpara's (2008) research on differences in the ethical perceptions of students before and after participating in the AICPA resulted in the conclusion that students began to have great attention to the ethical behavior of the accountant profession. This is supported by the research of Rogers and Smith (2008) regarding differences in the level of ethical decision making before and after taking ethics courses, stating the conclusion that there are differences in student responses after and before going through ethics courses when cases of unethical decision making are presented. Research by Nurita and Radianto (2008) regarding perceptions of the ethics of preparing financial statements for students also shows similar results, It can be concluded that students who have taken ethics education have a better perception of ethics in preparing financial statements than students who have not taken ethics education. From this explanation, it can be concluded that the longer a person takes ethics education, the person should have a better ethical perception. 
Based on these descriptions as well as in previous studies, in this study additional hypotheses can be proposed as follows:

$\mathrm{H} 2$ : There are differences in perceptions between teaching accountants and accounting students on the ethics of preparing financial statements

H3: There are differences in perceptions between accounting students and public accountants on the ethics of preparing financial statements

H4: There are differences in perceptions between teaching accountants and public accountants on the ethics of preparing financial statements

\section{Research Methods}

\subsection{Types of Research}

Based on the point of view of research objectives, this study is classified as a comparative study. Namely comparing groups of educating accountants, accounting students, and accountants.

\subsection{Operational Definition of Variables}

To provide a more specific understanding of the variables of this study, these variables are defined operationally and are presented as follows:

a) Earnings management

b) Reporting misstatements (mistate)

c) Disclosure

d) Costs and benefits (cost and benefit)

e) Responsibility

\subsection{Population and Sample}

The population in this study were accountants educating and accounting students from all universities in Semarang that have economics faculty majoring in accounting, as well as 15 public accounting firms in Semarang. Sampling in this study was taken by two sampling methods. Sampling for the group of accounting educators and students was carried out by purposive sampling.

\subsection{Validity and Reliability Test}

Testing the research instrument both in terms of validity and reliability of 185 respondents showed that the results of the research instrument used were valid, where the correlation value was greater than 0.3 (Masrun in Sugiono, 2017) and the reliability coefficient (Cronbach Alpha) was greater than 0.6 (Now 2018).

\subsection{Hypothesis testing}

This study is intended to see the differences between groups of respondents, therefore the hypothesis testing used is the Analysis of Variance (ANOVA) with a significance level $(\alpha)$ of $5 \%$. ANOVA is a method for testing the relationship between one dependent variable and one or more independent variables. ANOVA is used to determine the main effect (main effect) of categorical independent variables on metric variables. The main effect is the direct effect of the independent variable on the dependent variable.

The hypotheses to be tested in this study are:

H1: There are differences in perceptions between teaching accountants (accounting lecturers), accounting students, and accountants (auditors) on the ethics of preparing financial statements. 
$\mathrm{H} 2$ : There are differences in perceptions between teaching accountants and accounting students on the ethics of preparing financial statements

H3: There are differences in perceptions between teaching accountants and accountants on the ethics of preparing financial statements

H4: There are differences in perceptions between accounting students and accountants on the ethics of preparing financial statements

The analysis of the ANOVA results was carried out in the following steps:

\section{a. Test of Between Subject Effects}

ANOVA results will show the effect of the independent variable on the dependent through the Test of Between Subject Effects table. Whether or not the main effects of the independent variable on the dependent variable can be seen at the significance level of the independent variable. Hypothesis tested:

H01: There is no difference in the perceptions of teaching accountants, accounting students and accountants that do not affect the ethics of preparing financial statements.

H1 : There are differences in the perceptions of teaching accountants, accounting students and accountants affecting the ethics of preparing financial reports.

The basis for making decisions:

1) Significant if the value is sig. $<0.05$, meaning that there are differences in perceptions between the three groups (H1 accepted).

2) It is not significant if the sig value is $>0.05$, meaning that there is no difference in perception between the three groups ( $\mathrm{H} 1$ is rejected).

\section{b. Post Hoc Test}

To determine the difference in perceptions between groups in variables, the Post Hoc test was used in the form of the Turkey Test and the Bonferoni Test.

The difference in the average perception between the group of teaching accountants, accounting students, and accountants can be seen in the multiple comparison table in the mean difference column. Furthermore, to find out whether the difference in value in each group is significant or not, it can be seen in the sig value column. The basis for making decisions:

1) If the significance level is $>0.05$, there is no average difference between groups.

2) If the level of significance $<0.05$, there is a difference in the average between groups.

\section{Results and Discussion}

The determination of whether an item in the questionnaire is valid or not is done by using $r$ count. If the value of $r$ count $>r$ table then the item is valid, whereas if $r$ count $<r$ table it is said that the item used is invalid.

The results of the questionnaire validity test for all groups in this study are shown in the table below.

Table 1. All Groups Validity Test Results

\begin{tabular}{|c|c|c|c|}
\hline Indicator & Item & R count & Information \\
\hline Earning Management & EM & 0,375 & Valid \\
\hline \multirow{4}{*}{ Mistate } & M1 & 0,416 & Valid \\
\cline { 2 - 4 } & M2 & 0,521 & Valid \\
\cline { 2 - 4 } & M3 & 0,435 & Valid \\
\cline { 2 - 4 } & M4 & 0,535 & Valid \\
\hline Disclosure & D1 & 0,475 & Valid \\
\hline
\end{tabular}




\begin{tabular}{|c|c|c|c|}
\hline & D2 & 0,353 & Valid \\
\cline { 2 - 4 } & D3 & 0,445 & Valid \\
\hline \multirow{3}{*}{ Cost-Benefit } & CB1 & 0,634 & Valid \\
\cline { 2 - 4 } & CB2 & 0,616 & Valid \\
\cline { 2 - 4 } & CB3 & 0,521 & Valid \\
\hline Responsibility & R1 & 0,375 & Valid \\
\cline { 2 - 4 } & R2 & 0,433 & Valid \\
\hline
\end{tabular}

Source: Primary data processed, 2009 (Appendix C)

The value of $\mathrm{R}$ Table for the number of $\mathrm{N}$ of 185 at a significance level of $5 \%$ is 0.141. In table 4.10, it appears that the calculated $\mathrm{r}$ value for all indicators in research respondents is above $r$ table (0.141). This shows that all indicators used are valid or able to measure what will be measured.

The reliability test is used to show the stability and consistency of the instrument in measuring the same concept if it is measured again from time to time. Measurements used in this study used a one shot study using the Cronbach Alpha statistical test. A series of questions is said to be reliable if it has a Cronbach Alpha coefficient value above 0.6. Here is the reliability test:

Table 2. Reliability Test Reliability Statistics

\begin{tabular}{|c|c|c|}
\hline $\begin{array}{c}\text { Cronbach's } \\
\text { Alpha }\end{array}$ & $\begin{array}{c}\text { Cronbach's Alpha Based on } \\
\text { Standardized Items }\end{array}$ & N of Items \\
\hline .726 & .719 & 13 \\
\hline
\end{tabular}

Here shows the reliability value of all groups of 0.719 . It appears that all the Cronbach Alpha coefficient values are above 0.6 , so it is interpreted that the questionnaire series used in this study is reliable.

\subsection{Analysis of Variance (ANOVA)}

The hypothesis in this study was tested using ANOVA. The following is ANOVA in this study:

Table 3. ANOVA

\begin{tabular}{|l|r|r|r|r|r|}
\hline & \multicolumn{1}{|c|}{ Sum of Squares } & \multicolumn{1}{c|}{ Df } & Mean Square & F & \multicolumn{1}{c|}{ Sig. } \\
\hline Between Groups & 730.335 & 2 & 365.167 & 4.940 & .008 \\
Within Groups & 13453.806 & 182 & 73.922 & & \\
Total & 14184.141 & 184 & & & \\
\hline
\end{tabular}

The above gives a calculated $F$ value of 4,940 with a significance of 0.08 . The significance value is below 0.05 which indicates that there are significant differences in perceptions in the three research groups.

To see in detail the differences in each group, a Post Hoc test was performed which is shown in the Post Hoc table. The Post Hoc table shows that the significance between the teaching accountants group and the accounting student group is 0.017 for Tukey HSD and 0.018 for Benferroni. This value is below 0.05 , which indicates that there is a significant difference in perceptions between the Educator accountant group and the accounting student group. 
Table 4. Post Hoc

Multiple Comparisons

\begin{tabular}{|c|c|c|c|c|c|}
\hline & CODE & $\begin{array}{c}(\mathrm{J}) \\
\text { CODE }\end{array}$ & $\begin{array}{c}\text { Mean Difference } \\
(\mathrm{I}-\mathrm{J})\end{array}$ & Std. Error & Sig. \\
\hline \multirow[t]{6}{*}{ Tukey HSD } & 1 & 2 & $3.966^{*}$ & 1.429 & .017 \\
\hline & & 3 & -.214 & 1.704 & .991 \\
\hline & 2 & 1 & $-3.966^{*}$ & 1.429 & .017 \\
\hline & & 3 & $-4.180^{*}$ & 1.683 & .037 \\
\hline & 3 & 1 & .214 & 1.704 & .991 \\
\hline & & 2 & $4.180^{*}$ & 1.683 & .037 \\
\hline \multirow[t]{6}{*}{ Bonferroni } & 1 & 2 & $3.966^{*}$ & 1.429 & .018 \\
\hline & & 3 & -.214 & 1.704 & 1.000 \\
\hline & 2 & 1 & $-3.966^{*}$ & 1.429 & .018 \\
\hline & & 3 & $-4.180^{*}$ & 1.683 & .042 \\
\hline & 3 & 1 & .214 & 1.704 & 1.000 \\
\hline & & 2 & $4.180^{*}$ & 1.683 & .042 \\
\hline \multirow[t]{6}{*}{ Tamhane } & 1 & 2 & $3.966^{*}$ & 1.347 & .011 \\
\hline & & 3 & -.214 & 1.875 & .999 \\
\hline & 2 & 1 & $-3.966^{*}$ & 1.347 & .011 \\
\hline & & 3 & -4.180 & 1.868 & .083 \\
\hline & 3 & 1 & .214 & 1.875 & .999 \\
\hline & & 2 & 4.180 & 1.868 & .083 \\
\hline
\end{tabular}

*. The mean difference is significant at the 0.05 level.

Furthermore, the significance between the accounting student group and the auditor group was 0.037 (Tukey HSD) and 0.042 (Benferroni). This value is below 0.05, which indicates that there is a significant difference in perceptions between the accounting student group and the auditor group.

The third detail is between the teaching accountants group and the auditor group with a significance of 0.991 (Tukey HSD) and 1,000 (Benferroni). Both are above 0.05, which indicates that there is no significant difference between the educating accountants group and the auditor group.

\subsection{Differences in Perceptions of Educating Accountants, Accounting Students, and \\ Public Accountants on Ethics of Financial Reporting}

The results showed that there were significant differences in perceptions in the three research samples, namely the sample of teaching accountants, accounting students, and accountants. These results are indicated by the calculated $F$ value of 4,940 with a significance of $0.008(<0.05)$. This means that in general, the ethics of preparing financial statements is perceived differently by each group. This is possible because of the different characteristics of each group so that they have different perceptions about ethics in preparing financial statements.

The results of this study generally indicate that the level of education and experience is able to provide an accountant with a higher level of understanding. Thus, an accountant who has a sufficient level of education and also has relatively much experience can be said to have a better ethical perception of the preparation of financial statements. 


\subsection{Differences in Perceptions of Accounting Educators and Students of Accounting on Ethics of Financial Reporting}

A detailed review shows that there are differences in the ethical perceptions of preparing financial statements between the teaching accountants and the accounting student groups. This result is indicated by the Post Hoc test with a significance of 0.017 (Tukey HSD) and 0.018 (Benferroni), both of which are below 0.05.

The difference in the ethical perceptions of preparing financial reports between students and lecturers is possible due to differences in levels of education and experience. Students as novice accountants have a much lower education than educational accountants. Likewise in terms of experience, accounting students still lack experience compared to teaching accountants.

\subsection{Differences in Perceptions of Accounting Students and Public Accountants on Ethics of Financial Reporting}

Significant differences in the ethical perceptions of preparing financial statements were also found between accounting students and auditors. These results are indicated by the Post Hoc significance value of 0.037 (Tukey HSD) and 0.042 (Benferroni), both of which are below 0.05 .

Similar consideration is also given to this difference, namely because there are differences in educational levels and levels of experience that are relatively far different. At least auditors have studied up to S1 plus professional education Akt or even S2. In addition, auditors have relatively experience in auditing financial statements where students have minimal experience in this matter.

\subsection{Differences in Perceptions of Educating Accountants and Public Accountants on \\ Ethics of Financial Reporting}

This study did not find any differences in the ethical perceptions of financial reporting between educating accountants and public accountants (auditors). This result is indicated by the significance value in the Post Hoc test of 0.991 (Tukey HSD) and 1,000 (Benferroni), both of which are above 0.05.

The absence of this difference is possible because of the similarity in characteristics between teaching accountants and public accountants (auditors). These two groups have relatively the same level of education and experience.

The educational level of teaching accountants may be slightly higher than that of public accountants (auditors), however, in terms of experience, there are relatively more auditor accountants compared to teaching accountants. In addition, empirically there are also many educational accountants who also work as public accountants (auditors). Some of these similarities in characteristics lead to similar perceptions of the ethics of financial reporting between the two groups.

\section{Conclusion}

Based on the results of hypothesis testing about the perceptions of teaching accountants, accounting students, and public accountants on the ethics of preparing financial reports, it can be concluded that there are differences in perceptions between teaching accountants and accounting students, accounting students and accountants. However, there is no difference in perceptions between teaching accountants and accountants on the ethics of preparing financial statements. 
This conclusion is supported by the results of the following data analysis:

1. There are significant differences in the ethical perceptions of preparing financial statements between groups of accountants, educators, accounting students and accountants. This result is indicated by the calculated $F$ value of 4,940 with a significance of $0.008(<0.05)$.

2. There is a significant difference in the ethical perceptions of preparing financial statements between accounting accountants and accounting students. This result is indicated by the significance of the Post Hoc test of 0.017 (Tukey HSD) and 0.018 (Benferroni), both of which are below 0.05 .

3. There are significant differences in the ethical perceptions of preparing financial statements between accounting students and accountants. This result is indicated by the significance of the Post Hoc test of 0.037 (Tukey HSD) and 0.042 (Benferroni), both of which are below 0.05 .

4. There is no significant difference in the ethical perceptions of the preparation of financial statements between the investigating accountants and the auditor accountants. These results are indicated by the significance of the Post Hoc test of 0.991 (Tukey $H S D$ ) and 1,000 (Benferroni), both of which are above 0.05 .

The results of this study generally indicate that the level of education and experience is able to provide an accountant with a higher level of understanding. Thus, an accountant who has a sufficient level of education and also has relatively much experience can be said to have a better ethical perception of the preparation of financial statements.

\section{References}

Astri, Arfani NK, dan Noer Sasongko. 2005. "Analisis Perbedaan Pengaturan Laba (earning management) pada Kondisi Laba dan Rugi pada Perusahaan Manufaktur di Indonesia". Jurnal Akuntansi dan Keuangan (April), Vol. 4, No. 1.

Arindini, Ari, Andini. 2017. "Persepsi Mahasiswa Akuntansi Syariah Terhadap Etika Penyusunan Laporan Keuangan (Survei Pada Mahasiswa Akuntansi Syariah Fakultas Ekonomi Dan Bisnis Islam Institute Agama Islam). IAIN Surakarta.

Bank Indonesia. 2018. "Pedoman Akuntansi Pesantren". Jakarta: Departemen Ekonomi Dan Keuangan Syariah.

Bay, D.B. \& R.R. Greenberg, "The Relationship of the DIT and Behavior : A Replication". Issues in Accounting Education, vol 16 (2001), pp 367-380.

Clikeman, P.M. \& S. L. Henning, "The Socialization of undergraduate accounting students". Issues in Accounting Education, vol 15 (2000), pp 1-15.

Fitriani, Bayu Hardianthi. 2010. "Persepsi Dosen dan Mahasiswa Akuntansi terhadap Etika Penyusunan Laporan Keuangan". Universitas Pembangunan Nasional "Veteran": Jakarta.

Ghozali, Imam. 2006. Aplikasi Analisis Multivariate dengan Program Semarang: Badan Penerbit Universitas Diponegoro. SPSS.

Goa. J.C. \& L. Thorne, "An Introduction to the special issue on proffesionalism and ethics in Accounting Education'. Issues in Accounting Education, vol 19 (2004), pp 1-6.

Healy, P., \& J.M. Wahlen. "A Review of the Earnings Management Literature and its Implications for Standard Setting". Acconting Horizon, vol 13 (1999), pp. 365 - 383.

Harahap. 2001. Kritik Terhadap PSAK Perbankan Syari'ah, Media Riset Akuntansi, Auditing dan Informasi, Vol 1, No. 3.

Herawaty, Arleen, dan Yulius Kurnia Susanto. 2009. "Pengaruh Profesionalisme, Pengetahuan Mendeteksi Kekeliruan, dan Etika Profesi Terhadap Pertimbangan Tingkat Materialitas Akuntan Publik". Jurnal Akuntansi dan Keuangan (Mei), Vol. 11, No. 1. 
Hidayat, Imam. P. 2002, Kumpulan Artikel Akuntansi Syari'ah [Online]. Didapatkan: file:///E:/kumpulan artikel akuntansi syari'ah/tujuan-laporan- keuanganakuntansi.html. [8 Oktober 2012].

Ikatan Akuntan Indonesia. 2001. Pernyataan Standar Akuntansi Keuangan No. 101: Akuntansi Perbankan Syari'ah. Jakarta: Salemba Empat.

Ikatan Akuntan Indonesia, 2018. "PSAK 112 Akuntansi Wakaf” Jakarta: Geraha Akuntan

Indriantoro, Nur dan Bambang Supomo. 1998. Metodologi Penelitian Bisnis untuk Akuntansi dan Manajemen. Edisi Pertama. Yogyakarta: BPFE. UGM.

Jeffrey, C., "Ethical Development of Accounting Students, Non Accounting Business Students and Liberal Arts Students". Issues in Accounting Education, vol 6 (1993), pp 86 -96.

Kiger. C. E., "Making Ethics a pervasive component of Accounting Education'. Management Accounting Quarterly, vol 5 (2004), pp 42-54.

Marriott, P \& Neil Marriott, "Are we turning them on? A Longitudinal study of undergraduate accounting students' attitudes towards accounting as a profession".

Murtanto dan Marini. 2003. "Persepsi Akuntan Pria dan Akuntan Wanita serta Mahasiswa dan Mahasiswi terhadap Etika Bisnis dan Etika Profesi. Simponsium Nasional Akuntansi (SNA) VI. Surabaya: 16-17 Oktober.

Mc Carthy, I N., "Professional Ethics Code Conflict Situations: Ethical and Value Orientation of Collegiate Accounting Students". Journal of Business Ethics, vol 16 (1997), pp $1467-1473$.

Nurainiyah, Faiqatun. 2019. "penyusunan etika, tingkat religius, dan persepsi peran penyusun laporan keuangan pondok pesantren terhadap kualitas laporan keuangan pondok pesantren di kota semarang”. Skripsi, UIN Walisongo. Semarang.

Nurlan, Andi Besse. 2011. "Persepsi Akuntan dan Mahasiswa Jurusan Akuntansi terhadap Kode Etik Ikatan Akuntansi Indonesia". Skripsi. Universitas Hasanuddin: Makassar.

Radtke, R.R., "The Effects of Gender and Setting on Accountants' Ethically Sensitive Decisions". Journal of Business Ethics, 2000, pp 299-312.

Saputra, A. 2018. Allocation of Education Budget in Indonesia. Budapest International Research and Critics Institute-Journal (BIRCI-Journal), 142-148.

Sarwono, Jonathan. 2012. Metode Riset Skripsi Pendekatan Kuantitatif (Menggunakan Prosedur SPSS). Jakarta: PT. Elex Media Komputindo.

Setyaningrum, Anis. 2018. "Penyusunan Laporan Keuangan (Studi Kasus Pada Mahasiswa Akuntansi Fakultas Ekonomi Dan Bisnis Universitas Muhammadiyah Surakarta)". Surakarta.

Sihotang, I., M. 2019. Learning Lesson Study in Improving Accounting Learning Results. Budapest International Research and Critics in Linguistics and Education (BirLE) Journal, 529-537.

Smyth, M.L \& J.R. Davis, "Perceptions of Dishonesty Among Two-Year College Students: Academic versus Business Situations". Journal of Business Ethics, vol 51 (2004), pp 63

Sugiharto (2020) Geographical students' learning outcomes on basic political science by using cooperative learning model with Group Investigation (GI) type in State University of Medan, Indonesia, Journal of Human Behavior in the Social Environment, 30:4, 447-456, DOI: 10.1080/10911359.2019.1696261

Triyuwono, Iwan, dan Moh As'udi. 2001. Akuntansi Syari'ah: Memformulasikan Konsep Laba dalam konteks Metafora Zakat. Jakarta: Salemba Empat.

Triyuwono, Iwan. 2003. Sinergi Oposisi Biner: Formulasi Tujaan Dasar Laporan Keuangan Akuntansi Syari'ah. Journal of Islamic Economics Vol. 4, No. 1.

Wyatt, A.R., “ Accounting Professionalism - They just don't get it?". Accounting Horizons, vol 18 (2004), pp 45-53. 